INVITED ARTICLE

\title{
How to Audit Transfusion Practices in the Intensive Care Unit?
}

\author{
Ganshyam Jagathkar ${ }^{1}$, Srinivas Samavedam ${ }^{2}$
}

\begin{abstract}
Blood transfusions are one of the most commonly prescribed interventions in the critically ill patients. Apart from being a life saving intervention, they can also be associated with life threatening complications. Despite multiple trials and guidelines, there is a wide variability and lack of adherence to the guideline's. Auditing transfusion practices help us in introspecting and modifying our prescriptions as per the recommended standards.

Keywords: Audit, Blood transfusion, Guidelines

Indian Journal of Critical Care Medicine (2019): 10.5005/jp-journals-10071-23255
\end{abstract}

\section{INTRODUCTION}

Blood transfusions have been one of the most commonly used interventions in the critically ill patients. For a long time RBC transfusions were given with an aim of achieving a $\mathrm{Hb}$ level of more than $10 \mathrm{~g} / \mathrm{dL}$, despite the lack of data supporting this. The rationale behind this practice was a presumption that anemia is poorly tolerated in the sick and increasing the $\mathrm{Hb}$ concentration will increase the $\mathrm{O}_{2}$ delivery to the tissues, thereby narrowing the gap between the $\mathrm{O}_{2}$ demand and supply. ${ }^{1}$ However, transfusions are not completely safe. Apart from the high risk for infectious complications, blood transfusions also pose a significant risk for life threatening noninfectious complications like transfusion related acute lung injury (TRALI) and transfusion associated circulatory overload (TACO). They have also shown to have immunomodulatory effects increasing the risk of nosocomial infections. ${ }^{2}$

\section{Need for Auditing Transfusion Practices}

Translational science refers to the process of improving patient care by converting observations from research into clinical practice. ${ }^{3}$ The average time taken for such changes is estimated to be around 17 years - secondary translational gap. ${ }^{4,5}$ There are very few trials in the field of intensive care, which have changed the practice in a big way. The TRICC study is one such trial and considered a landmark paper as it changed the way of prescribing blood to the critically ill-before the TRICC trial, it was a routine to target a $\mathrm{Hb}$ concentration of more than $10 \mathrm{~g} / \mathrm{dL}$. Post TRICC trial multiple other papers have suggested a noninferior and at times superior outcomes with a restrictive strategy compared to liberal strategy. ${ }^{6,7}$ Based on the available literature, numerous guidelines have favored a restrictive strategy.

It has been shown widely that despite the availability of evidence and implementation programs, guidelines are inconsistently followed. ${ }^{8,9}$

\section{Audits}

Audit is a method of improving quality of patient care by collecting data and comparing them with the accepted standards and incorporating necessary changes. Audits help in objective introspection and if combined with feedback and education can improve the performance of the team. Blood transfusion is a life saving intervention and can be associated with a significant number of incidents which can be life threatening. It has also been shown
1Department of Critical Care, Medicover Hospital, Hyderabad, Telangana, India

${ }^{2}$ Department of Critical Care, Virinchi Hospital, Hyderabad, Telangana, India

Corresponding Author: Ganshyam Jagathkar, Department of Critical Care, Medicover Hospital, Hyderabad, Telangana, India, Phone: 9949001344, e-mail: drganshyam@gmail.com

How to cite this article: Jagathkar G, Samavedam S. How to Audit Transfusion Practices in the Intensive Care Unit? Indian J Crit Care Med 2019;23(Suppl 3):S212-S214.

Source of support: Nil

Conflict of interest: None

that a good number of these are due to human errors. ${ }^{10}$ Regular audits help in identifying areas of error thereby decreasing the number of transfusion related adverse incidents. They can also help in reviewing prescription practices and reduce the number and cost related to blood transfusions.

\section{How to Audit Blood Transfusion?}

Audits can be retrospective or prospective. They have to be individualized to the institutional needs and can be modified from time to time based on the evolution of evidence. Retrospective audits help in understanding and analyzing the current institutional practices and compare them with the recommended guidelines. This can form the basis to make necessary changes and subsequently be the platform for prospective audits. Data collection and interpretation should always be combined with feedback and educational programs to improve the overall outcomes of patients (Fig. 1).

The audit team usually comprises the intensivist, nurse, blood bank officer and the quality team. However, this can be modified from time to time based on the availability and need of the institute. The following data should be collected and analyzed regularly:

- Transfusion trigger: pretransfusion hemoglobin level (Table 1).

- Baseline demographic data including the severity of illness and the diagnosis

- Indication for blood transfusion

- Prescribing authority: It is common practice in a country like India for non-intensivists to prescribe blood transfusion. Audits can help in reviewing this and limiting the number of prescribers for blood transfusion, thereby decreasing the overall usage of blood products.

(0) The Author(s). 2019 Open Access This article is distributed under the terms of the Creative Commons Attribution 4.0 International License (https://creativecommons. org/licenses/by-nc/4.0/), which permits unrestricted use, distribution, and non-commercial reproduction in any medium, provided you give appropriate credit to the original author(s) and the source, provide a link to the Creative Commons license, and indicate if changes were made. The Creative Commons Public Domain Dedication waiver (http://creativecommons.org/publicdomain/zero/1.0/) applies to the data made available in this article, unless otherwise stated. 
Table 1:Transfusion trigger's

\begin{tabular}{|c|c|c|}
\hline Guideline group/body & $\begin{array}{l}\text { Year of } \\
\text { publication }\end{array}$ & Suggested transfusion triggers \\
\hline AABB & 2016 & 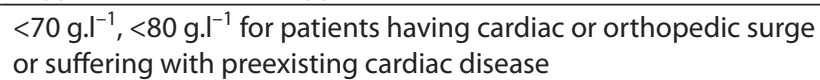 \\
\hline $\begin{array}{l}\text { Cochrane database of systematic reviews-Transfusion } \\
\text { thresholds and other strategies for guiding allogeneic red } \\
\text { blood cell transfusion }\end{array}$ & 2016 & $70 \mathrm{g.l}^{-1}-80 \mathrm{g. \textrm {l } ^ { - 1 }}$ \\
\hline $\begin{array}{l}\text { AAGBI guidelines: The use of blood components and their } \\
\text { alternatives } 2016\end{array}$ & 2016 & 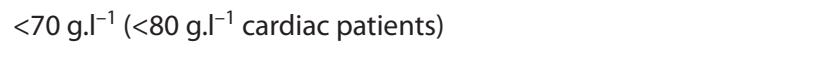 \\
\hline NICE guidelines NG 24-Blood transfusion & 2015 & 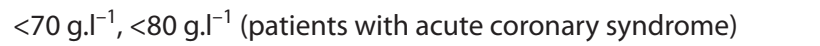 \\
\hline $\begin{array}{l}\text { British Society for Hematology-Guidelines on the } \\
\text { management of anemia and red cell transfusion in adult } \\
\text { critically ill patients }\end{array}$ & 2012 & $<70{\mathrm{~g} . \mathrm{I}^{-1}}^{-1}$ \\
\hline
\end{tabular}

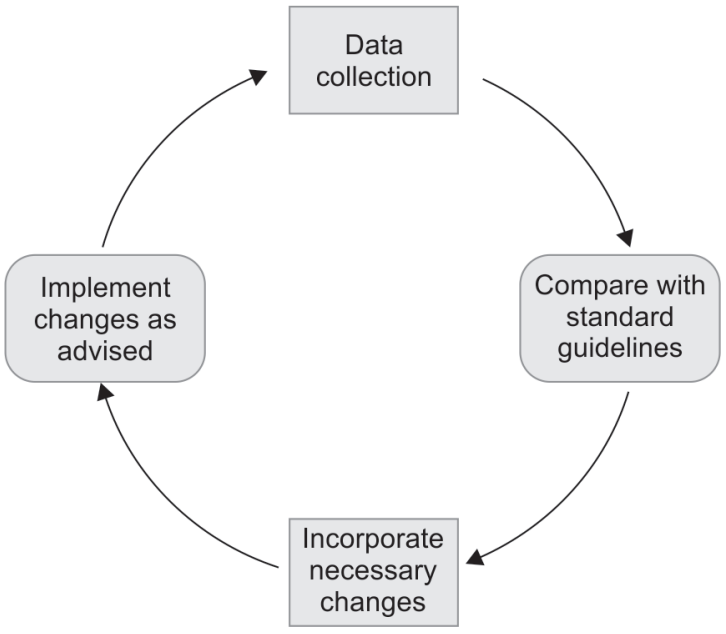

Fig. 1: Audit process

- No of units transfused: Most of the guidelines recommend the transfusion of a single unit (except in a bleeding patient) and rechecking the $\mathrm{Hb}$ levels before transfusing the second unit

- Timing of transfusion: During day hours vs night hours

- Consent form

- Turnaround time (TAT) post-transfusion request

- Verification of blood products before transfusion

- Transfusion reactions

- No of units wasted: Issued but not transfused

- Blood components: Platelet counts, coagulation studies. It is also important to note the presence or absence of bleeding/planned procedures/surgeries/risk factors for bleeding.

As far as blood component transfusion practices are concerned, the usage is comparatively less than RBC and the indications are on a broader definition well defined. However, it is not an uncommon finding to see prescriptions for plasma and platelets in routine practice for nonbleeding patients. The transfusion of blood components is both expensive and can be associated with adverse effects. Hence, whenever audit for transfusions are done, data should also include the use of blood component therapy on similar lines and compared.

\section{Audit of Transfusion Bundles}

The institute of Health Improvement has suggested the idea of implementing a group of evidence-based interventions as a bundle to improve the outcomes. ${ }^{11-13}$ Borgert et al. developed and
Table 2: Transfusion bundle interventions ${ }^{14}$

- Verification of the Hb measurement reliability

- Transfusions given according to patient's individual $\mathrm{Hb}$-threshold, i.e. transfusion trigger

- Verification of obtained informed consent

- Verification of the right patient by two persons independently

- Verification of the right blood product by two persons independently

implemented a transfusion bundle and showed a reduction in the number of inappropriate RBC transfusions. ${ }^{14}$ The same authors through a timely audit and feedback demonstrated a significant increase in the compliance of the transfusion bundle, ${ }^{15}$ suggesting this could be used as an audit tool to improve the overall utilization of the blood products (Table 2).

\section{Conclusion}

Blood transfusion is an important and common intervention in the critically ill patients. Despite a large body of evidence and established guidelines, there is considerable variation in clinical practices with respect to blood transfusion. Audit of transfusion practices has shown to improve the adherence to guidelines and also decrease the number of transfusions. Each institute should have defined periodic audits to analyze and improve their transfusion practices.

\section{References}

1. Sakr Y, Vincent JL. Should red cell transfusion be individualized? Yes. Intensive Care Med. 2015;41:1973-1976.

2. Rohde JM, Dimcheff DE, Blumberg N, Saint S, Langa KM, Kuhn L, et al. Health care-associated infection after red blood cell transfusion: a systematic review and meta-analysis. JAMA. 2014;311:1317-1326.

3. Gilliland CT, Sittampalam GS, Wang PY, Ryan PE. The translational science-training program at $\mathrm{NIH}$ : introducing early career researchers to the science and operation of translation of basic research to medical interventions. Biochemistry and Molecular Biology Education 2017;45:13-24.

4. Morris ZS, Wooding S, Grant J. The answer is 17 years, what is the question: understanding time lags in translational research. Journal of the Royal Society of Medicine 2011;104:510-520.

5. Cooksey D. A review of UK health research funding, 2006. https:// www.gov.uk/government/uploads/system/uploads/ attachment data/file/228984/0118404881.pdf (accessed 06/11/2016).

6. Corwin HL, Gettinger A, Pearl RG, Fink MP, Levy MM, Abraham E, et al. The CRIT Study: anemia and blood transfusion in the critically ill - Current clinical practice in the United States. Critical Care Medicine 2004;32:39-52. 
7. Vincent JL, Baron JF, Reinhart K, Gattinoni L, Thijs L, Webb A, et al. Anemia and blood transfusion in critically ill patients. Journal of the American Medical Association 2002;288:1499-1507.

8. Cabana MD, Rand CS, Powe NR, Wu AW, Wilson MH, Abboud PA, et al. Why don't physicians follow clinical practice guidelines? A framework for improvement. JAMA1999;282:1458-1465.

9. Astrid Norgaard, Trine Honnens de Lichtenberg, Jens Nielsen, Pär I Johansson. Monitoring compliance with transfusion guidelines in hospital departments by electronic data capture. Blood Transfus 2014;12:509-519.

10. Bolton-Maggs, PHB and Cohen, H. (2013) Serious hazards of transfusion (SHOT) haemovigilance and progress is improving transfusion safety. Br J Haemalot, 163, 303-314.

11. Resar R, Griffin FA, Haraden C, Nolan TW. Using Care Bundles to Improve Health Care Quality. IHI Innovation Series white paper. Cambridge, Massachusetts: Institute for Healthcare Improvement, 2012. www.ihi.org/ resources/Pages/IHIWhitePapers/ UsingCareBundles.aspx (23 June 2015, date last accessed).
12. Berenholtz SM, Pronovost PJ, Lipsett PA, Hobson D, Earsing K, Farley $\mathrm{JE}$, et al. Eliminating catheterrelated bloodstream infections in the intensive care unit. Crit Care Med 2004;32:2014-2020.

13. Peter Pronovost, Dale Needham, Sean Berenholtz, David Sinopoli, Haitao Chu, Sara Cosgrove, et al. An intervention to decrease catheter-related bloodstream infections in the ICU. N Engl J Med 2006;355:2725-2732.

14. Borgert M, Binnekade J, Paulus F, Vroom M, Vlaar A, Goossens A, et al. Implementation of a transfusion bundle reduces inappropriate red blood cell transfusions in intensive care - a before and after study. Transfus Med. 2016 Dec;26(6):432-439. doi: 10.1111/tme.12364. Epub 2016 Oct 11.

15. Borgert M, Binnekade J, Paulus F, Goossens A, Vroom M, Dongelmans D. Timely individual audit and feedback significantly improves transfusion bundle compliance-a comparative study. Int J Qual Health Care. 2016 Oct;28(5):601-607. Epub 2016 Jul 15 